\title{
2007-2009 Bear Market and Corporate Takeovers
}

\author{
Ozge Uygur ${ }^{1}$, Gulser Meric ${ }^{1} \&$ Ilhan Meric ${ }^{2}$ \\ ${ }^{1}$ Department of Accounting and Finance, Rowan University, U.S.A. \\ ${ }^{2}$ Department of Finance and Economics, Rider University, U.S.A. \\ Correspondence: Gulser Meric, Professor of Finance, Department of Finance and Accounting, Rohrer College of \\ Business, Rowan University, Glassboro, NJ 08028, U.S.A. E-mail: Meric@rowan.edu.
}

Received: October 13, 2012

Accepted: January 3, 2013

Online Published: January 8, 2013

doi:10.5539/ijef.v5n2p78

URL: http://dx.doi.org/10.5539/ijef.v5n2p78

\begin{abstract}
Mergers and acquisitions (M\&A) are among the most popular research topics in finance. The synergistic benefits of and the market reaction to mergers have been studied extensively. However, the impact of financial/economic crises on M\&A activities has not been studied sufficiently. In this empirical study, we make a contribution on this subject by studying the financial characteristics of acquisition targets in the U.S. before, during, and after the October 9, 2007-March 9, 2009 bear market. The MANOVA (multivariate analysis of variance) test statistics indicate that the overall financial characteristics of the acquired firms were not significantly different from the financial characteristics of the non-acquired control group firms during the bear market and immediately before and after the bear market. However, we find that the acquiring firms preferred targets with significantly higher total assets turnover ratios before the bear market, with significantly higher inventory turnover ratios during the bear market, and with significantly lower capital expenditure ratios after the bear market.
\end{abstract}

Keywords: 2007-2009 bear market, acquisition target, financial characteristics, MANOVA (multivariate analysis of variance)

JEL Classification: G30, G34

\section{Introduction}

Mergers and acquisitions (M\&A) have been studied extensively in finance. Poor post-merger performance and bad market reaction to mergers are generally explained by reasons such as hubris (Roll, 1986), managerial entrenchment (Jensen 1986; Morck et al., 1988; Shleifer and Vishny, 1989), empire building (Rhoades, 1983; Black, 1989) and bad judgment (Morck et al., 1990). The focus of most M\&A studies has been generally limited to specific countries (see, e.g., Rose, 1987; Trifts and Scanlon, 1987). The M\&A literature has traditionally focused more on the acquirers than on the targets. Meric et al. (1991) and Aghigbe et al (2004) have studied the financial characteristics of and the gains to bank acquisition targets.

Value creation in mergers has received considerable attention. Value creation and destruction in mergers have been evaluated extensively in the context of diversification (Lang and Stulz, 1994; Berger and Ofek, 1995; Servaes, 1996). Datta et al (1992) study the factors that affect value creation in mergers and acquisitions. Becher (2004) and Beitel et al. (2004) have studied value creation in bank mergers. An extensive literature review of M\&A studies can be found in Schweiger and Goulet (2000), Cartwright and Schoenberg (2006), and DeYoung et al. (2009).

The effect of economic/financial crisis periods on M\&A activities has not been studied sufficiently in the extant literature. In this paper, we make a contribution on this subject by studying the financial characteristics of U.S. companies that have been takeover targets during the 2007-2009 bear market. This was the worst bear market in U.S. history since the Great Depression. U.S. stocks lost 55 percent of their market value from October 9, 2007 to March 9, 2009 and many U.S. companies became attractive acquisition targets to both domestic and foreign buyers during this period. For comparison, we also study the January 1, 2005-October 8, 2007 period immediately before and the March 10, 2009-December 31, 2011 period immediately after the bear market.

\section{Methodology}

Comparing the financial characteristics of different groups of firms with financial ratios has long been a popular research methodology in finance. Altman (1968), Edmister (1972), and Dambolena and Khoury (1980) predict bankruptcy by comparing the financial ratios of bankrupt and healthy firms. Stevens (1973), Belkaoui (1978), 
Rege (1984), Meric et al. (1991), and Uygur et al. (2012) use financial ratios to identify the financial characteristics of companies which become the target of corporate takeovers. Hutchinson et al. (1988) use financial ratios to identify the financial characteristics of companies, which achieve stock market quotation in the UK. Meric et al. (2000) compare the financial characteristics of Japanese kieretsu-affiliated and independent firms with financial ratios.

Several studies use financial ratios to compare the financial characteristics of firms in different countries. Kester (1986) and Wald (1999) compare the capital and ownership structures of firms in different countries. Meric and Meric $(1989,1994)$ compare the financial characteristics of U.S. and Japanese manufacturing firms. Meric at al. (2003) compare the financial characteristics of U.S. and Canadian manufacturing firms. Meric et al. (2002) compare the financial characteristics of U.S., E.U., and Japanese manufacturing firms.

MDA (Multiple Discriminant Analysis) and MANOVA (Multivariate Analysis of Variance) are the two multivariate statistical methods most commonly used in previous studies to compare the financial characteristics of different groups of firms (see, e.g., Stevens, 1973; Meric et al., 1991). In this paper, we use the MANOVA method (see: Johnson and Wichern, 2007) to compare the financial characteristics of U.S. firms that have been takeover targets with the financial characteristics of a control group of comparable size firms.

ANOVA (analysis of variance) is a special case of MANOVA that focuses on a single variable (see: Wilks, 1932; Bartlett, 1936). It is a statistical inference method to test for significant differences between means of two or more groups. The $F$ statistic is given by

$$
F=\frac{S S B}{S S W}
$$

Where SSB is data variation between the means of different groups and SSW is data variation within each group.

MANOVA (multivariate analysis of variance) is a generalized form of ANOVA to multi-variant cases. In contrast to the univariate ANOVA, the total variation in MANOVA is not only contributed by the variation within and between groups, it may also be contributed by the interactions among different variables.

The multivariate test statistic Wilks' Lambda is given by

$$
\Lambda_{W i k s}=\frac{\left|A_{S S W}\right|}{\left|A_{S S W}+A_{S S B}\right|}
$$

where $|\boldsymbol{A}|$ is the determinant of matrix $\boldsymbol{A}$. Wilks' Lambda can also be transferred into an F statistic in hypothesis testing (see: Bartlett, 1938).

\section{Data}

Our data collection process consists of three steps. First, we identify the U.S. firms that were acquisition targets during the 2005-2011 period. Secondly, we group these target firms into three categories based on their merger announcement dates. Merger announcements between January 1, 2005 and October 8, 2007 are considered as "Before Crisis" mergers, those between October 9, 2007 and March 9, 2009 are consider as "During Crisis" mergers, and those between March 10, 2009 and December 31, 2011 are considered as "After Crisis" mergers. Lastly, we collect the data from the financial statements of the target U.S. companies.

The mergers and acquisitions data are collected from the Capital IQ database. We first identified the U.S. public firms that were acquisition targets during the 2005-2011 period. We then collected the annual data from the year-end financial statements of the firms from the Compustat database for the fiscal year one year prior to the year of the merger. In order to mitigate the excessive influence of the outliers, we winsorized our sample at the $1 \%$ and $99 \%$ levels.

As the final step of our data collection, we created a matched-sample control group for the target firms. We matched every target company with a same-size non-acquired public company from the same industry. After determining the matched sample of control group firms, we collected their annual financial statements data from the Compustat database.

Overall, our sample consists of 321 target firms and 321 control group firms. The break-down of the sample based on the merger announcement date is displayed in Table 1 . The summary statistics of the targets firms and the control group firms are presented in Table 2. The financial ratios used in the comparisons as measures of the financial characteristics of the firms are presented in Table 3. 
Table 1. Sample Information and Number of Observations

\begin{tabular}{lcccc}
\hline & Before Crisis & During Crisis & After Crisis & Full Sample \\
\hline Target Companies & 83 & 51 & 86 & 220 \\
Control Group Companies & 45 & 25 & 31 & 101 \\
\hline All Companies & 128 & 76 & 117 & 321 \\
\hline
\end{tabular}

Table 2. Summary Statistics for the Target and Control Group Companies

\begin{tabular}{lllllll}
\hline & \multicolumn{2}{l}{ Target Companies } & \multicolumn{5}{l}{ Control Group Companies } \\
\hline Variables & Mean & Median & Std. Dev. & Mean & Median & Std. Dev. \\
\hline Total Assets & $1,652.11$ & 360.31 & $4,552.23$ & $5,355.90$ & $1,151.85$ & $18,162.13$ \\
Current Assets & 621.04 & 179.74 & $1,847.09$ & $1,494.22$ & 371.09 & $4,811.61$ \\
Net Fixed Assets & $1,031.07$ & 134.23 & $3,034.85$ & $3,861.68$ & 555.55 & $13,477.80$ \\
& & & & & & \\
Sales & $1,425.75$ & 355.33 & $3,578.92$ & $4,305.08$ & 553.52 & $14,111.47$ \\
Net Income & 88.42 & 11.42 & 436.08 & 278.88 & 24.94 & 862.16 \\
& & & & & & \\
Stock Price per Share & 19.46 & 13.14 & 18.79 & 24.25 & & 23.90 \\
\hline
\end{tabular}

Table 3. Financial Ratios Used in the Study as Measures of Firm Financial Characteristics

\begin{tabular}{|c|c|}
\hline Financial Ratio Name & Financial Ratio Definition \\
\hline \multicolumn{2}{|c|}{ Liquidity } \\
\hline Current Ratio (CUR) & Current Assets / Current Liabilities \\
\hline Quick Ratio (QUR) & (Current Assets - Inventories) / Current Liabilities \\
\hline Liquid Assets Ratio (LAR) & $($ Cash + Marketable Securities $) /$ Total Assets \\
\hline \multicolumn{2}{|c|}{ Asset Management (Turnover) Ratios } \\
\hline Accounts Receivable Turnover (ART) & Sales / Accounts Receivable \\
\hline Inventory Turnover (INT) & Sales / Inventory \\
\hline Fixed Assets Turnover (FAT) & Sales / Net Fixed Assets \\
\hline Total Assets Turnover (TAT) & Sales / Total Assets \\
\hline \multicolumn{2}{|c|}{ Financial Leverage } \\
\hline Total Debt Ratio (TDR) & Total Debt / Total Assets \\
\hline \multicolumn{2}{|c|}{ Profitability } \\
\hline Net Profit Margin (NPM) & Net Income / Sales \\
\hline Operating Profit Margin (OPM) & Operating Income / Sales \\
\hline Return on Assets (ROA) & Net Income / Total Assets \\
\hline Earning Power Ratio (EPR) & Operating Income / Total Assets \\
\hline Return on Equity (ROE) & Net Income / Common Equity \\
\hline \multicolumn{2}{|c|}{ Growth } \\
\hline Capital Expenditures Ratios (CER) & Capital Expenditures / Total Assets \\
\hline \multicolumn{2}{|c|}{ Market Value } \\
\hline Market-to-Book Ratio (MBK) & Market Value Per Share / Book Value Per Share \\
\hline
\end{tabular}

\section{Empirical Findings}

\subsection{Pre-Crisis Period}

The MANOVA test statistics for the pre-crisis period are presented in Table 4. The multivariate F statistic is used to test the null hypothesis that the mean ratio/variable vector for the target firms is not significantly different from the mean ratio/variable vector for the control group. The multivariate F statistic in the table indicates that the null hypothesis should be accepted (i.e., the overall financial characteristics of the two groups of firms are not significantly different).

The univariate $\mathrm{F}$ statistics show that the financial characteristics of the two groups of firms are significantly different only in terms of total assets turnover at the ten-percent level. The test result indicates that the acquiring firms preferred targets with significantly higher total assets turnover ratios during the pre-crisis period. 


\subsection{Crisis Period}

The MANOVA test statistics for the crisis period are presented in Table 5. The multivariate test statistic in the table indicates that the overall financial characteristics of the two groups of firms are not significantly different in the crisis period. However, the univariate test statistics show that the two groups of firms are significantly different in terms of the inventory turnover ratio at the ten-percent level. It appears that the acquiring firms preferred targets with higher inventory turnover rates (i.e., targets with a lower level of inventories relative to sales) during this period.

Table 4. MANOVA Statistics for the Pre-Crisis Period: Target Firms vs. Control Group Firms

\begin{tabular}{|c|c|c|c|c|}
\hline \multirow{3}{*}{ Financial Ratios } & \multicolumn{2}{|c|}{ Means and Standard Deviationst' } & \multirow{2}{*}{\multicolumn{2}{|c|}{ Univariate Statistics }} \\
\hline & Acquisition & Control & & \\
\hline & Targets & Group & F Value & P Value \\
\hline \multicolumn{5}{|l|}{ Liquidity } \\
\hline Current Ratio & $\begin{array}{l}2.89 \\
(2.37)\end{array}$ & $\begin{array}{l}3.28 \\
(3.28)\end{array}$ & 1.19 & 0.28 \\
\hline Quick Ratio & $\begin{array}{l}2.23 \\
(2.17)\end{array}$ & $\begin{array}{l}2.41 \\
(2.25)\end{array}$ & 0.44 & 0.51 \\
\hline Liquid Assets Ratio & $\begin{array}{l}0.20 \\
(0.19) \\
\end{array}$ & $\begin{array}{l}0.21 \\
(0.20) \\
\end{array}$ & 0.12 & 0.73 \\
\hline \multicolumn{5}{|c|}{ Asset Management (Turnover) Ratios } \\
\hline Accounts Rec. Turnover & $\begin{array}{l}12.88 \\
(22.62)\end{array}$ & $\begin{array}{c}12.06 \\
(25.20)\end{array}$ & 0.08 & 0.78 \\
\hline Inventory Turnover & $\begin{array}{l}26.19 \\
(50.45)\end{array}$ & $\begin{array}{c}22.48 \\
(44.00)\end{array}$ & 0.39 & 0.53 \\
\hline Fixed Assets Turnover & $\begin{array}{l}11.53 \\
(18.36)\end{array}$ & $\begin{array}{c}9.69 \\
(14.44)\end{array}$ & 0.80 & 0.37 \\
\hline Total Assets Turnover & $\begin{array}{l}1.11 \\
(0.62)\end{array}$ & $\begin{array}{c}0.98 \\
(0.51) \\
\end{array}$ & $3.39 *$ & 0.07 \\
\hline \multicolumn{5}{|l|}{ Financial Leverage } \\
\hline Total Debt Ratio & $\begin{array}{l}42.1 \% \\
(19.9 \%) \\
\end{array}$ & $\begin{array}{l}41.8 \% \\
(20.7 \%) \\
\end{array}$ & 0.02 & 0.90 \\
\hline \multicolumn{5}{|l|}{ Profitability } \\
\hline Net Profit Margin & $\begin{array}{c}0.2 \% \\
(39.7 \%)\end{array}$ & $\begin{array}{r}-5.1 \% \\
(52.1 \%)\end{array}$ & 0.85 & 0.36 \\
\hline Operating Profit Margin & $\begin{array}{c}2.7 \% \\
(38.7 \%)\end{array}$ & $\begin{array}{r}-0.2 \% \\
(54.2 \%)\end{array}$ & 0.24 & 0.63 \\
\hline Return on Assets & $\begin{array}{c}3.5 \% \\
(11.2 \%)\end{array}$ & $\begin{array}{r}3.7 \% \\
(11.0 \%)\end{array}$ & 1.34 & 0.25 \\
\hline Earning Power Ratio & $\begin{array}{c}6.2 \% \\
(12.8 \%)\end{array}$ & $\begin{array}{r}5.4 \% \\
(13.7 \%)\end{array}$ & 0.24 & 0.63 \\
\hline Return on Equity & $\begin{array}{c}5.3 \% \\
(28.3 \%) \\
\end{array}$ & $\begin{array}{r}2.9 \% \\
(25.4 \%) \\
\end{array}$ & 0.50 & 0.48 \\
\hline \multicolumn{5}{|l|}{ Growth } \\
\hline Cap. Expenditure Ratio & $\begin{array}{l}5.0 \% \\
(5.0 \%) \\
\end{array}$ & $\begin{array}{c}5.0 \% \\
(5.1 \%) \\
\end{array}$ & 0.01 & 0.94 \\
\hline \multicolumn{5}{|l|}{ Market Value } \\
\hline Market-to-Book Ratio & $\begin{array}{l}2.77 \\
(2.21) \\
\end{array}$ & $\begin{array}{r}2.95 \\
(2.85) \\
\end{array}$ & 0.30 & 0.58 \\
\hline Multivariate Statistics & & & 0.76 & 0.72 \\
\hline
\end{tabular}

$\dagger$ The figures in parentheses are the standard deviations.

***, **, * indicate that the difference is significant at the 1-percent, 5-percent, and 10-percent levels, respectively. 
Table 5. MANOVA Statistics for the Crisis Period: Target Firms vs. Control Group Firms

\begin{tabular}{|c|c|c|c|c|}
\hline \multirow{3}{*}{ Financial Ratios } & \multicolumn{2}{|c|}{ Means and Standard Deviationst } & \multirow{2}{*}{\multicolumn{2}{|c|}{ Univariate Statistics }} \\
\hline & Acquisition & Control & & \\
\hline & Targets & Group & F Value & P Value \\
\hline \multicolumn{5}{|l|}{ Liquidity } \\
\hline Current Ratio & $\begin{array}{c}2.95 \\
(2.47)\end{array}$ & $\begin{array}{c}3.00 \\
(2.23)\end{array}$ & 0.02 & 0.90 \\
\hline Quick Ratio & $\begin{array}{c}2.33 \\
(2.28)\end{array}$ & $\begin{array}{c}2.31 \\
(2.06)\end{array}$ & 0.00 & 0.97 \\
\hline Liquid Assets Ratio & $\begin{array}{c}0.20 \\
(0.21)\end{array}$ & $\begin{array}{c}0.19 \\
(0.19)\end{array}$ & 0.02 & 0.90 \\
\hline \multicolumn{5}{|c|}{ Asset Management (Turnover) Ratios } \\
\hline Accounts Rec. Turnover & $\begin{array}{c}9.03 \\
(9.12)\end{array}$ & $\begin{array}{c}10.33 \\
(14.93)\end{array}$ & 0.42 & 0.52 \\
\hline Inventory Turnover & $\begin{array}{c}28.71 \\
(59.80)\end{array}$ & $\begin{array}{c}15.40 \\
(20.93)\end{array}$ & $3.36^{*}$ & 0.07 \\
\hline Fixed Assets Turnover & $\begin{array}{c}10.90 \\
(14.26)\end{array}$ & $\begin{array}{c}8.22 \\
(13.62)\end{array}$ & 1.41 & 0.24 \\
\hline Total Assets Turnover & $\begin{array}{c}1.01 \\
(0.61) \\
\end{array}$ & $\begin{array}{c}0.93 \\
(0.46) \\
\end{array}$ & 0.91 & 0.34 \\
\hline \multicolumn{5}{|l|}{ Financial Leverage } \\
\hline Total Debt Ratio & $\begin{array}{c}43.6 \% \\
(23.3 \%)\end{array}$ & $\begin{array}{c}44.0 \% \\
(21.6 \%)\end{array}$ & 0.01 & 0.92 \\
\hline \multicolumn{5}{|l|}{ Profitability } \\
\hline Net Profit Margin & $\begin{array}{c}-1.9 \% \\
(46.2 \%)\end{array}$ & $\begin{array}{r}-3.8 \% \\
(30.7 \%)\end{array}$ & 1.02 & 0.31 \\
\hline Operating Profit Margin & $\begin{array}{c}-0.5 \% \\
(54.3 \%)\end{array}$ & $\begin{array}{r}-3.8 \% \\
(30.7 \%)\end{array}$ & 1.11 & 0.29 \\
\hline Return on Assets & $\begin{array}{c}2.2 \% \\
(13.5 \%)\end{array}$ & $\begin{array}{l}-0.9 \% \\
(19.9 \%)\end{array}$ & 1.25 & 0.27 \\
\hline Earning Power Ratio & $\begin{array}{c}4.5 \% \\
(14.5 \%)\end{array}$ & $\begin{array}{c}1.8 \% \\
(19.0 \%)\end{array}$ & 0.99 & 0.32 \\
\hline Return on Equity & $\begin{array}{c}4.8 \% \\
(29.2 \%)\end{array}$ & $\begin{array}{c}-4.8 \% \\
(48.0 \%)\end{array}$ & 2.24 & 0.14 \\
\hline \multicolumn{5}{|l|}{ Growth } \\
\hline Cap. Expenditure Ratio & $\begin{array}{c}4.3 \% \\
(3.7 \%) \\
\end{array}$ & $\begin{array}{c}4.9 \% \\
(5.3 \%) \\
\end{array}$ & 0.70 & 0.41 \\
\hline \multicolumn{5}{|l|}{ Market Value } \\
\hline Market-to-Book Ratio & $\begin{array}{c}3.11 \\
(2.68) \\
\end{array}$ & $\begin{array}{r}3.37 \\
(3.47) \\
\end{array}$ & 0.27 & 0.61 \\
\hline Multivariate Statistics: & & & 0.75 & 0.73 \\
\hline
\end{tabular}

$\dagger$ The figures in parentheses are the standard deviations.

$* * *, * *, *$ indicate that the difference is significant at the 1-percent, 5-percent, and 10-percent levels, respectively.

\subsection{Post-Crisis Period}

The MANOVA test statistics for the post-crisis period are presented in Table 6. The multivariate F statistic in the table indicates that, as in the previous two periods, the overall financial characteristics of the two groups of firms are not significantly different. However, the univariate $\mathrm{F}$ statistic shows that the capital expenditure ratio is significantly lower for the target firms than for the control group firms at the ten-percent level. It implies that the acquiring firms preferred targets with lower capital expenditure ratios during this period. These firms presumably had lower market valuations compared with growth firms with greater capital expenditure ratios making them less expensive targets. 
Table 6. MANOVA Statistics for the Post-Crisis Period: Target Firms vs. Control Group Firms

\begin{tabular}{|c|c|c|c|c|}
\hline \multirow{3}{*}{ Financial Ratios } & \multicolumn{2}{|c|}{ Means and Standard Deviationst } & \multirow{2}{*}{\multicolumn{2}{|c|}{ Univariate Statistics }} \\
\hline & Acquisition & Control & & \\
\hline & Targets & Group & F Value & P Value \\
\hline \multicolumn{5}{|l|}{ Liquidity } \\
\hline Current Ratio & $\begin{array}{c}2.81 \\
(1.89)\end{array}$ & $\begin{array}{c}3.14 \\
(2.57)\end{array}$ & 1.27 & 0.26 \\
\hline Quick Ratio & $\begin{array}{c}2.21 \\
(1.64)\end{array}$ & $\begin{array}{c}2.38 \\
(2.02)\end{array}$ & 0.52 & 0.47 \\
\hline Liquid Assets Ratio & $\begin{array}{r}0.22 \\
(0.20) \\
\end{array}$ & $\begin{array}{r}0.22 \\
(0.21) \\
\end{array}$ & 0.03 & 0.86 \\
\hline \multicolumn{5}{|c|}{ Asset Management (Turnover) Ratios } \\
\hline Accounts Rec. Turnover & $\begin{array}{c}8.60 \\
(9.58)\end{array}$ & $\begin{array}{c}9.17 \\
(10.39)\end{array}$ & 0.19 & 0.66 \\
\hline Inventory Turnover & $\begin{array}{c}26.42 \\
(62.54)\end{array}$ & $\begin{array}{c}24.39 \\
(50.71)\end{array}$ & 0.07 & 0.79 \\
\hline Fixed Assets Turnover & $\begin{array}{c}10.81 \\
(16.26)\end{array}$ & $\begin{array}{c}11.14 \\
(17.55)\end{array}$ & 0.02 & 0.88 \\
\hline Total Assets Turnover & $\begin{array}{l}0.93 \\
(0.53) \\
\end{array}$ & $\begin{array}{c}0.86 \\
(0.46) \\
\end{array}$ & 0.98 & 0.32 \\
\hline \multicolumn{5}{|l|}{ Financial Leverage } \\
\hline Total Debt Ratio & $\begin{array}{c}45.1 \% \\
(19.8 \%) \\
\end{array}$ & $\begin{array}{c}43.7 \% \\
(23.0 \%) \\
\end{array}$ & 0.25 & 0.62 \\
\hline \multicolumn{5}{|l|}{ Profitability } \\
\hline Net Profit Margin & $\begin{array}{c}-8.2 \% \\
(54.5 \%)\end{array}$ & $\begin{array}{r}-7.4 \% \\
(59.2 \%)\end{array}$ & 0.01 & 0.92 \\
\hline Operating Profit Margin & $\begin{array}{c}-1.1 \% \\
(49.9 \%)\end{array}$ & $\begin{array}{r}-1.5 \% \\
(58.4 \%)\end{array}$ & 0.00 & 0.96 \\
\hline Return on Assets & $\begin{array}{c}-2.9 \% \\
(14.3 \%)\end{array}$ & $\begin{array}{r}-2.4 \% \\
(18.3 \%)\end{array}$ & 0.05 & 0.83 \\
\hline Earning Power Ratio & $\begin{array}{c}2.2 \% \\
(10.9 \%)\end{array}$ & $\begin{array}{r}2.0 \% \\
(15.9 \%)\end{array}$ & 0.01 & 0.92 \\
\hline Return on Equity & $\begin{array}{c}-6.8 \% \\
(33.7 \%) \\
\end{array}$ & $\begin{array}{l}-12.5 \% \\
(99.2 \%) \\
\end{array}$ & 0.35 & 0.56 \\
\hline \multicolumn{5}{|l|}{ Growth } \\
\hline Cap. Expenditure Ratio & $\begin{array}{c}3.8 \% \\
(3.6 \%) \\
\end{array}$ & $\begin{array}{c}4.8 \% \\
(5.0 \%) \\
\end{array}$ & $3.24 *$ & 0.07 \\
\hline \multicolumn{5}{|l|}{ Market Value } \\
\hline Market-to-Book Ratio & $\begin{array}{r}2.17 \\
(1.75) \\
\end{array}$ & $\begin{array}{r}2.24 \\
(2.45) \\
\end{array}$ & 0.07 & 0.80 \\
\hline Multivariate Statistics: & & & 0.75 & 0.73 \\
\hline
\end{tabular}

$\dagger$ The figures in parentheses are the standard deviations.

$* * *, * *, *$ indicate that the difference is significant at the 1-percent, 5-percent, and 10-percent levels, respectively.

\section{Summary and Conclusions}

Mergers and acquisitions (M\&A) are among the most popular research topics in finance. However, M\&A activities during economic/financial crisis periods have been understudied. In this paper, we make a contribution on this subject by studying the financial characteristics of acquisition targets before, during, and after the October 9, 2007-March 9, 2009 bear market.

We find that acquiring firms preferred targets with higher total assets turnover ratios before the bear market, with higher inventory turnover ratios during the bear market, and with lower capital expenditure ratios after the bear market.

In the pre-crisis period, the total assets turnover ratio is significantly higher in the acquired target firms than in the non-acquired control group firms. It appears that acquiring firms saw greater profit and growth potential in targets that are able to achieve high total assets turnover rates during this relatively normal period before the bear market.

During the crisis period, the inventory turnover ratio is significantly lower in the acquired target firms than in the non-acquired control group firms. The acquiring firms appear to have avoided targets with a low inventory 
turnover and excessive inventories during this period. The expectation on the part of the acquiring firms must have been that it would be extremely difficult to liquidate the inventories of the target in a bear market and recessionary economy.

In the post-crisis period, the capital expenditure ratio is significantly lower in the acquired target firms than in the non-acquired control group firms. A strong bull market followed the bear market for several months during the March-July, 2009 period. The market values of growth firms with high capital expenditure ratios increased sharply during this period. Our finding implies that the acquiring firms preferred targets with lower capital expenditure ratios (and with relatively lower market valuations) in the post-bear market period.

Our findings in this study can provide valuable insights to managers of potential acquiring and target firms with respect to what characteristics are considered to be important in acquisition targets during normal, crisis, and post-crisis periods. The information provided in this study may enable the managers of both acquiring and target firms to adopt the right strategies to earn the maximum benefit from mergers and acquisitions.

\section{References}

Akhigbe, A., Madura, J., \& Whyte, A. M. (2004). Partial Participation and the Gains to Bank Merger Targets. Journal of Financial services Research, 26(1), 55-71. http://dx.doi.org/ 10.1023/B:FINA.0000029657.34575.d2

Altman, E. I. (1968). Financial Ratios, Discriminant Analysis, and the Prediction of Corporate Bankruptcy. Journal of Finance, 23(4), 589-609. http://dx.doi.org/10.1111/ j.1540-6261. 1968.tb00843.x

Bartllett, M. S. (1938). Further Aspects of the Theory of Multiple Regression. Proceedings of the Cambridge Philosophical Society, 34, 33-40. http://dx.doi.org/10.1017/S0305004100019897

Becher, D. A. (2000). The Valuation Effects of Bank Mergers. Journal of Corporate Finance, 6(2), 189-214. http://dx.doi.org/10.1016/S0929-1199(00)00013-4

Beitel, P., Schiereck, D., \& Wahrenburg, M. (2004). Explaining M\&A Success in European Banks. European Financial Management, 10(1), 109-139. http://dx.doi.org/10.1111/j.1468-036X. 2004.00242.x

Belkaoui, A. (1978). Financial Ratios as Predictors of Canadian Takeovers. Journal of Business Finance and Accounting, 5(1), 93-108. http://dx.doi.org/10.1111/j.1468-5957.1978.tb00177. x

Berger, P. G., \& Ofek, E. (1995). Diversification's Effect on Firm Value. Journal of Financial Economics, 37, 39-65. http://dx.doi.org/10.1016/0304-405X(94)00798-6

Black, B. (1989). Bidder Overpayment in Takeovers. Stanford Law Review, 41(3), 597-660. http://dx.doi.org/10.2307/1228881

Cartwright, S., \& Schoenberg, R. (2006). Thirty Years of Mergers and Acquisitions Research: Recent Advances and Future Opportunities. British Journal of Management, 17(1), 1-5. http://dx.doi.org/10.1111/j.1467-8551.2006.00475.x

Dambolena, I. G., \& Khoury, S. J. (1980). Ratio Stability and Corporate Failure. Journal of Finance, 35(4), 1017-1026. http://dx.doi.org/10.1111/j.1540-6261.1980.tb03517.x

Datta, D. K., Pinches, G. E., \& Narayanan, V. K. (1992). Factors Influencing Wealth Creation from Margers and Acquisitions: Meta Analysis. Strategic Management Journal, 13(1), 67-84. http://dx.doi.org/10.1002/smj.4250130106

DeYoung, R., Evanoff, D. D., \& Molyneux, P. (2009). Mergers and Acquisitions of Financial Institutions: A Review of the Post-2000 Literature. Journal of Financial services Research, 36(2-3), 87-110. http://dx.doi.org/10.1007/s10693-009-0066-7

Edmister, R. O. (1972). An Empirical Test of Financial Ratio Analysis for Small Business Failure Prediction. Journal of Financial and Quantitative Analysis, 7(2), 1477-1493. http://dx.doi.org/10.2307/2329929

Hutchinson, P., Meric, I., \& Meric, G. (1988). The Financial Characteristics of Small Firms which Achieve Quotation on the UK Unlisted Securities Market. Journal of Business Finance and Accounting, 15(1), 9-20. http://dx.doi.org/10.1111/j.1468-5957.1988.tb00116.x

Jensen, M. C. (1986). Agency Costs of Free Cash Flow, Corporate Finance, and Takeovers. American Economic Review, 76(2), 323-329.

Johnson, R. D., \& Wichern, D. W. (2007). Applied Multivariate Statistical Analysis (6 ${ }^{\text {th }}$ ed.), Englewood Cliffs, NJ: Prentice Hall. 
Kester, W. C. (1986). Capital and ownership structure: A comparison of United States and Japanese manufacturing firms. Financial Management, 15(1), 5-16. http://dx.doi.org/ 10.2307/3665273

Lang, L. H. P., \& Stulz, R. M. (1994). Tobin's Q, Corporate Diversification, and Firm Performance. Journal of Political Economy, 102, 1248-1280. http://dx.doi.org/ 10.1086/261970

Meric, G., Kyj, L., Welsh, C., \& Meric, I. (2000). A Comparison of the Financial Characteristics of Japanese Kieretsu-Affiliated and Independent Firms. Multinational Business Review, 8(2), 26-30.

Meric, G., Leveen, S. S., \& Meric, I. (1991). The Financial Characteristics of Commercial Banks Involved in Interstate Acquisitions. Financial Review, 26(1), 75-90. http://dx.doi.org/ 10.1111/j.1540-6288.1991.tb00370.x

Meric, I., \& Meric, G. (1989). A comparison of the financial characteristics of U.S. and Japanese manufacturing firms. Financial Management-FM Letters, 18(4), 9-10. http://dx.doi.org/ 10.2307/3665789

Meric, I., \& Meric, G. (1994). A comparison of the financial characteristics of United States and Japanese Manufacturing Firms. Global Finance Journal, 5(1), 205-218. http://dx.doi.org/ 10.1016/1044-0283(94)90004-3

Meric, I., Gishlick, H. E., McCall, C. W., \& Meric, G. (2003). A comparison of the financial characteristics of U.S. and Canadian manufacturing firms. Midwestern Business and Economic Review, 31(1), 25-33.

Meric, I., S. Weidman, S., Welsh, C., \& Meric, G. (2002). A comparison of the financial characteristics of U.S., EU, and Japanese manufacturing firms. American Business Review, 20(2), 119-125.

Morck, R., Shleifer, A., \& Vishny, R. W. (1988). Management Ownership and Market Valuation: An Empirical $\begin{array}{llll}\text { Analysis. Journal of } & \text { Financial 293-315. }\end{array}$ http://dx.doi.org/10.1016/0304-405X(88)90048-7

Morck, R., Shleifer, A., \& Vishny, R. W. (1990). Do Managerial Objectives Drive Bad Acquisitions? Journal of Finance, 45(1), 31-48. http://dx.doi.org/10.1111/j. 15406261.1990. tb05079.x

Rege, U. P. (1984). Accounting Ratios to Locate Take-Over Targets. Journal of Business Finance and Accounting, 11(3), 301-311. http://dx.doi.org/10.1111/j.1468-5957. 1984. tb00751.x

Rhoades, S. A. (1983). Power, Empire Building, and Mergers. Lexington, MA: D. C. Heath \& Co.

Roll, R. (1986). The Hubris Hypothesis of Corporate Takeovers. Journal of Business, 59(2), 197-216. http://dx.doi.org/10.1086/296325

Rose, P. S. (1987). The Impact of Mergers in Banking: Evidence from a Nationwide Sample of Federally Chartered Banks. Journal of Economics and Business, 39(4), 289-313. http://dx.doi.org/10.1016/0148-6195(87)90024-5

Schweger, D. M., \& Goulet, P. K. (2000). Integrating Mergers and Acquisitions: An International Research Review. Advances in Mergers and Acquisitions, 1, 61-91. http://dx.doi.org/10.1016/S1479-361X(00)01004-8

Servaes, H. (1996). The Value of Diversification during the Conglomerate Merger Wave. Journal of Finance, 5l(4), 1201-1225. http://dx.doi.org/10.1111/j.1540-6261.1996. tb04067. x

Shleifer, A., \& Vishny, R. W. (1989). Management Entrenchment: The Case of Manager-Specific Investments. Journal of Financial Economics, 25(1), 123-139. http://dx.doi.org/ 10.1016/0304-405X(89)90099-8

Stevens, D. L. (1973). Financial Characteristics of Merged Firms: A Multivariate Analysis. Journal of Financial and Quantitative Analysis, 8(2), 149-158. http://dx.doi.org/ 10.2307/2330007

Trifts, J. W. \& Scanlon, K. P. (1987). Interstate Bank Mergers: The Early Evidence. Journal of Financial Research, 10(4), 305-312.

Uygur, O., Meric, G., \& Meric, I. (2012). The Financial Characteristics of U.S. Companies Acquired by Foreign Companies. Global Journal of Business Research, 7(1), 1-8.

Wald, J. K. (1999). How firm characteristics affect capital structure: An international comparison. Journal of Financial Research, 22(2), 161-187.

Wilks, S. S. (1932). Certain Generalizations in the Analysis of Variance. Biometrika, 24, 471-494. 